\title{
PENGENALAN PENGOLAHAN SUSU KAMBING DI KECAMATAN SUKADANA KABUPATEN LAMPUNG TIMUR \\ [Introduction of Goat Milk Processing in Sub-district of Sukadana, District of East Lampung of the Lampung Province]
}

\author{
Ratna Wylis Arief*, Novilia Santri dan Robet Asnawi \\ Balai Pengkajian Teknologi Pertanian (BPTP) Lampung \\ Jl. Z. A. Pagar Alam No. 1a Rajabasa-Bandar Lampung \\ *Email korespondensi: r_wylis@yahoo.co.id
}

Diterima : 23 Agustus 2017

Disetujui : 13 Februari 2018

\begin{abstract}
Goat milk is easily damaged if handling poorly, so it has a relatively short shelf life. To handle the excess production of goat milk, the most appropriate ways to preserve goat milk through processing and increase the consumption of processed milk by the community. The purpose of the study was to produce some products from goat milk processing and to know the panelist acceptance of these products, as well as calculate the cost of production. This research was conducted in Muara Jaya Village, Sukadana District, East Lampung District, from June to August 2016, in collaboration with KWT Mentari. The types of processed goat milk introduced were flavored goat milk, strawberry flavored goat milk ice cream, manggo flavored goat milk ice cream, and goat milk candy. Each type of processed goat milk was tested proximate analysis for fresh goat milk, the level of consumer preference, consumer acceptance rate, and breakeven point, to known how much the selling price per unit. Observation of consumer acceptance level was carried out by using hedonic scale (scale 1-5) from 20 panelists and breakeven price was calculated by comparing the total production cost with the resulting yield. The collected data were analyzed statistically and if there was any difference of the mean value, the data was further analyzed by DMRT test at $5 \%$ level. The results showed that the development of goat milk production was very pospective because goat milk had high protein content and low fat content so good for health; processed goat milk products introduced by consumers, with an average score of $>$ 3 ; the result of break even analysis showed that goat milk processing had prospect to be developed, because the price of its break point was still reachable by consumer ie: Rp.45.500/liter od flavored goat milk; Rp.61.267/liter of strawberry flavore goat milk ice cream, Rp.55.933/liter of manggo flavored goat milk ice cream, and Rp. 1.479/each of caramel flavored goat milk.
\end{abstract}

Keywords: introduction, processing, goat milk.

\begin{abstract}
ABSTRAK
Susu kambing mudah rusak bila penanganannya kurang baik, sehingga mempunyai masa simpan relatif singkat. Untuk menangani kelebihan produksi susu kambing, langkah yang paling tepat adalah dengan mengawetkan susu kambing melalui proses pengolahan dan meningkatkant konsumsi susu olahan oleh masyarakat. Tujuan Penelitian adalah untuk menghasilkan beberapa jenis produk dari pengolahan susu kambing dan mengetahui penerimaan panelis terhadap produk-produk tersebut, serta menghitung biaya produksinya. Penelitian ini dilaksanakan di Desa Muara Jaya, Kecamatan Sukadana, Kabupaten Lampung Timur, dari bulan Juni sampai Agustus 2016, bekerjasama dengan KWT Mentari. Jenis olahan susu kambing yang perkenalkan adalah susu kambing aroma rempah, es krim susu kambing rasa strawberry, es krim susu kambing rasa mangga, dan permen susu
\end{abstract}


kambing. Tiap jenis olahan susu kambing tersebut diuji tingkat kesukaan konsumen dan titik impas masing-masing, sehingga diketahui berapa harga per satuannya bila ingin diusahakan secara komersial. Parameter pengamatan meliputi, analisa proksimat untuk susu kambing segar, tingkat penerimaan konsumen, dan harga titik impas dari masingmasing jenis olahan. Pengamatan tingkat penerimaan konsumen dilakukan dengan menggunakan skala hedonik (skala 1-5) dari 20 panelis dan harga titik impas dihitung dengan membandingkan total biaya produksi dengan rendeman yang dihasilkan. Data yang terkumpul dianalisis secara statistik dan bila ada perbedaan nilai tengah dilanjutkan dengan uji DMRT pada taraf 5\%. Hasil penelitian menunjukkan bahwa pengembangan olahan susu kambing sangat pospektif karena susu kambing memiliki kadar protein yang tinggi dan kadar lemak yang rendah sehingga baik untuk kesehatan; hasil olahan susu kambing yang diintroduksikan disukai oleh konsumen, dengan nilai skor rata-rata $>3$; hasil analisis titik impas menunjukkan bahwa pengolahan susu kambing memiliki prospek untuk dikembangkan, karena harga titik impasnya masih terjangkau konsumen yaitu: Rp.45.500,/liter susu kambing aroma rempah; Rp.61.267/liter es krim susu kambing rasa starwberry, Rp.55.933,-/liter es krim susu kambing rasa kweni, dan Rp. 1.479/buah permen karamel susu kambing.

Kata kunci: introduksi, pengolahan, susu kambing

\section{PENDAHULUAN}

Susu merupakan bahan makanan yang bernilai gizi tinggi yang diperoleh dari hasil pemerahan hewan seperti sapi, kerbau, kuda, kambing dan unta. Komponen penting dalam air susu adalah protein, lemak, vitamin, mineral, laktosa serta enzim-enzim dan beberapa jenis mikroba yang bermanfaat bagi kesehatan sebagai probiotik (Thai Agricultural Standard, 2008). Dibanding susu sapi, susu kambing memiliki kandungan gizi yang lebih unggul, selain itu lemak dan protein pada susu kambing lebih mudah dicerna dan kandungan vitamin B1 nya lebih tinggi dibanding susu sapi.

Komposisi susu hewan mamalia sangat beragam tergantung pada beberapa faktor antara lain jenisnya, waktu laktasi, pakan, interval pemerahan, suhu dan umur hewan (Sudono et al., 1989). Hasil penelitian Arifin et al., (2016), menunjukkan bahwa susu kambing segar hasil pemerahan sore memiliki sifat fisik, kimia dan mikrobiologi yang lebih baik dibanding susu kambing segar hasil pemerahan pagi hari.

Susu mudah rusak bila penanganannya kurang baik, sehingga mempunyai masa simpan relatif singkat. Untuk menangani kelebihan produksi susu, langkah yang paling tepat adalah dengan mengawetkan susu untuk memperpanjang masa simpan melalui proses pengolahan, dan di tingkat masyarakat konsumsi susu olahan lebih banyak dibandingkan dengan konsumsi susu segar. Pengolahan susu tidak saja dilakukan oleh industri pengolahan susu tetapi juga dapat dilakukan pada industri rumah tangga. Pengolahan susu pada skala industri rumah tangga dapat memberikan nilai tambah yang besar bagi peternak sapi dan kambing perah, dan susu dalam bentuk olahan merupakan alternatif untuk mengkonsumsi susu dalam bentuk lain, karena sebagian masyarakat kurang suka mengkonsumsi susu dalam bentuk segar. Produk-produk olahan berbasis susu yang banyak dilakukan pada industri pengolahan susu adalah susu homogenisasi, susu skim dan 
krim, mentega, susu kental manis, susu bubuk, yoghurt, kefir, susu pasteurisasi atau sterilisasi, keju, es krim, karamel atau kembang gula, dodol susu, tahu susu dan kerupuk susu.

Kambing perah merupakan komoditas baru di Indonesi yang kemungkinan memiliki prospek pengembangan yang baik. Kambing perah yang banyak dikembangkan di Indonesia adalah kambing peranakan Etawah (PE), yang umumnya masih lebih dominan sebagai sumber daging dibandingkan dengan sumber air susu. Susu kambing belum dikenal secara luas seperti susu sapi padahal memiliki komposisi kimia yang cukup baik, dan memberi manfaat yang baik untuk kesehatan tubuh karena susu banyak mengandung nutrisi dan komponen bioaktif yang berperan menjaga kesehatan tubuh. Hasil penelitian Sunarlim dkk (1992) menunjukkan bahwa susu kambing mempunyai kandungan protein $4,3 \%$ dan kandungan lemak 2,8\%, nilai ini relatif lebih baikdibandingkan kandungan susu sapi yang mempunyai kandunga protein $3,8 \%$ dan kandungan lemak sebesar $5,0 \%$. Selain itu dibandingkan dengan susu sapi, susu kambing lebih mudah dicerna, karena ukuran molekul lemak susu kambing lebih kecil dan secara alamiah sudah berada dalam keadaan homogen (Sunarlim dkk, 1992; Sinn, 1983).

Permasalahan yang dihadapi adalah belum membudayanya mengkonsumsi susu kambing karena tahap pengenalan atau promosi untuk mengkonsusmi susu kambing masih sangat kurang. Selain itu, sebagian masyarakat kurang menyukai aroma khas daging kambing masih tercium pada susu kambing. Pengolahan susu kambing dengan cara fermentasi atau penambahan bahan tambahan makanan merupakan salah satu cara untuk menekan aroma khas pada susu kambing. Untuk itu peningkatan kualitas yoghurt dari susu kambing diharapkan merupakan jawaban untuk terjadinya peningkatan konsumsi susu kambing yang berupa produk hasil olahannya (Effendi et al., 2009).

Masyarakat pada umumnya dan masyarakat di sekitar lokasi penelitian pada khususnya terbiasa mengkonsumsi susu sapi dan menggunakan susu sapi sebagai bahan baku untuk membuat aneka olahan makanan, namun bagi sebagian masyarakat yang alergi terhadap susu sapi akan memilih mengkonsumsi susu kambing, selain itu probiotik yang terkandung dalam susu kambing akan memberikan manfaat yang baik untuk kesehatan manusia. Oleh sebab itu pada penelitian ini diintroduksikan pembuatan olahan susu dengan bahan bakunya susu kambing dengan tujuan untuk mengetahui tingkat kesukaan dan prospek pengembangan dan hasil olahan susu kambing.

\section{BAHAN DAN METODE}

\section{Tempat dan Waktu Penelitian}

Penelitian ini dilaksanakan di Desa Muara Jaya, Kecamatan Sukadana, Kabupaten Lampung Timur, sejak bulan Juni sampai Agustus 2016 bekerjasama dengan KWT Mentari.

\section{Bahan dan Alat}

Bahan-bahan yang digunakan pada penelitian ini adalah: susu kambing, gula, garam, kayu manis, jahe, maizena, santan, buah kweni, buah strawberry, mentega, dan lain-lain.

Alat-alat yang digunakan pada penelitian ini adalah: kompor, panci, kuali, 
pengaduk, blender, freezer, thermometer, dan lain-lain.

\section{Metode Penelitian}

Jenis olahan susu kambing yang diintroduksikan adalah susu kambing aroma rempah, es krim susu kambing rasa strawberry, es krim susu kambing rasa mangga, dan permen susu kambing. Selanjutnya olahan susu kambing tersebut diuji tingkat kesukaan konsumen dan titik impas untuk masingmasing jenis olahan, sehingga diketahui berapa harga per satuannya bila ingin diusahakan secara komersial.

\section{Pembuatan Susu Kambing Segar Aroma Rempah}

Pembuatan susu kambing aroma rempah dilakukan dengan mencampurkan susu kambing + kayu manis+ jahe+ gula merah. Kemudian campuran tersebut dimasak pada suhu $40^{\circ} \mathrm{C}$ selama 10 menit dan biarkan sampa dingin. Selanjutnya dimasukkan dalam botol kemasan dan disimpan dalam lemari es.

\section{Pembuatan Es Krim Susu Kambing Rasa Mangga Kweni}

Proses pembuatan es krim susu kambing rasa mangga kweni sama dengan proses pembuatan es krim susu kambing rasa starwberry seperti yang tertera pada Gambar 1, hanya buah strawberry diganti dengan buah mangga kweni.

\section{Pembuatan Permen Karamel Susu Kambing}

Gula pasir dipanaskan sampai menjadi karamel, kemudian tambahkan susu kambing dan mentega. Masak dengan api kecil sampai mengental, tuang ke dalam cetakan dan bekukan di dalam freezer. Setelah mengeras dipotong-potong sesuai dengan ukuran yang diinginkan

\section{Parameter Pengamatan dan Analisis Data}

Parameter pengamatan meliputi tingkat kesukaan konsumen dan harga titik impas dari masing-masing jenis olahan. Analisis kandungan mutu susu kambing yang digunakan sebagai bahan baku pada penelitian ini dilakukan di laboratorium Teknologi Hasil Pertanian Politeknik Negeri Lampung. Pengamatan tingkat kesukaan konsumen dilakukan dengan menggunakan skala hedonik (skala 1-5) dari 20 panelis, perhitungan harga titik impas menggunakan metode Soekartiwi (1995) dengan membandingkan total biaya produksi dengan rendeman yang dihasilkan. Data yang terkumpul dianalisis secara statistik dan bila ada perbedaan nilai tengah dilanjutkan dengan uji DMRT pada taraf $5 \%$. 


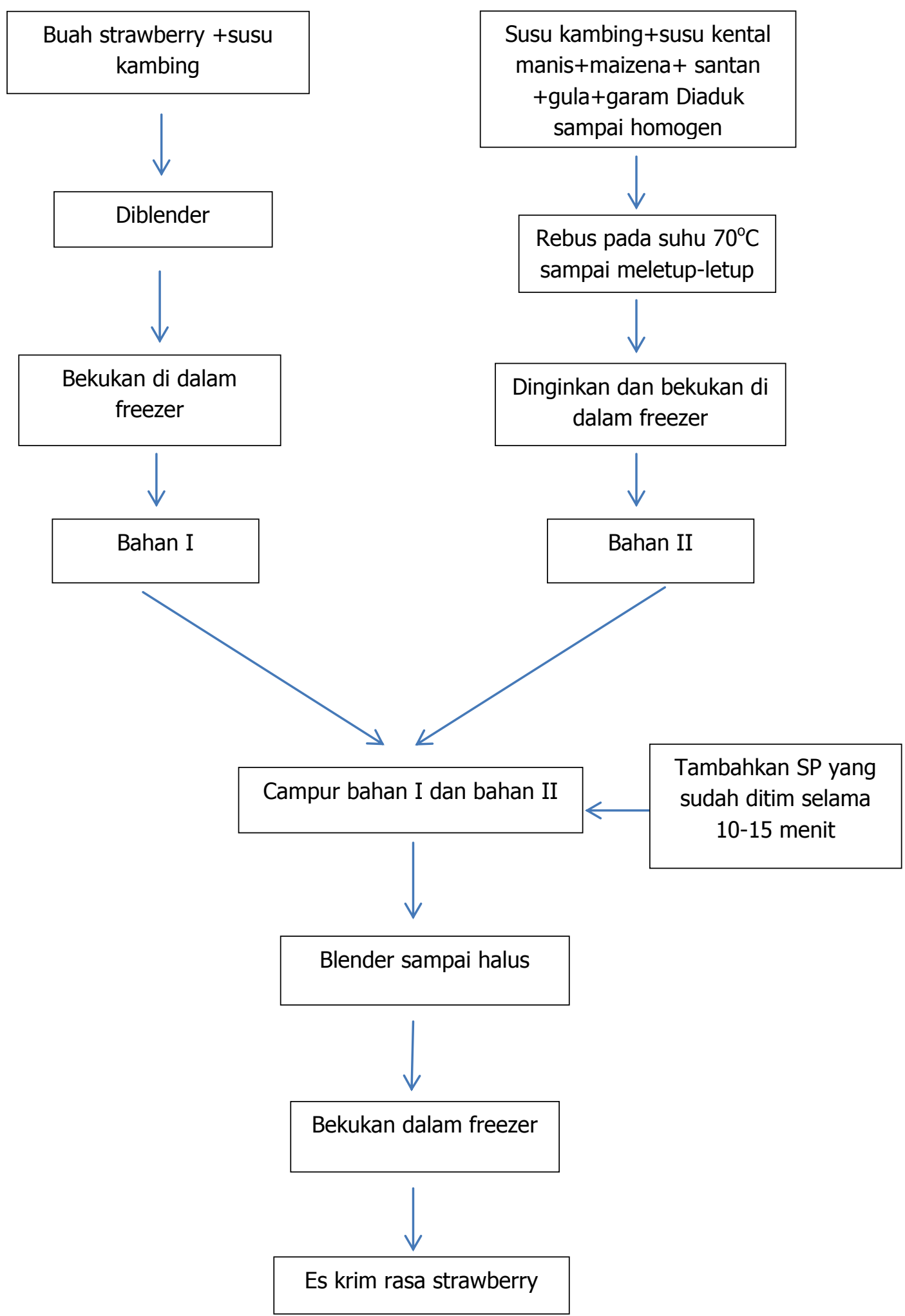

Gambar 1. Diagram Alir Pembuatan Es Krim Susu Kambing Rasa Strawberry 


\section{HASIL DAN PEMBAHASAN}

Hasil pengamatan tingkat kesukaan konsumen terhadap olahan susu kambing disajikan dalam Tabel 1.

Tabel 1. Tingkat kesukaan konsumen terhadap produk olahan susu kambing

\begin{tabular}{lcccc}
\hline \multirow{1}{*}{ Jenis Olahan } & \multicolumn{4}{c}{ Tingkat Kesukaan } \\
\cline { 2 - 5 } & Warna & Aroma & Rasa & $\begin{array}{c}\text { Penerimaan } \\
\text { Umum }\end{array}$ \\
\hline $\begin{array}{l}\text { Susu kambing aroma rempah } \\
\text { Es krim susu kambing rasa }\end{array}$ & 3,53 (b) & 3,47 (b) & 3,80 (b) & 3,40 (c) \\
strawberry & 3,07 (c) & 3,13 (c) & 3,20 (c) & 3,73 (b) \\
$\begin{array}{l}\text { Es krim susu kambing rasa } \\
\text { kweni }\end{array}$ & 3,87 (a) & 4,27 (a) & 4,47 (a) & 4,07 (a) \\
Permen susu kambing & 3,47 (b) & 3,20 (c) & 2,87 (d) & 2,40 (d) \\
\hline
\end{tabular}

Keterangan: Angka-angka pada kolom yang sama, dan diikuti dengan huruf yang sama tidak berbeda nyata dengan uji DMRT pada taraf $5 \%$.

$$
\text { Keterangan: } \quad \begin{array}{ll}
1 & =\text { tidak suka } \\
& 2=\text { agak suka } \\
3 & =\text { suka } \\
4 & =\text { sangat suka } \\
5 & =\text { amat sangat suka }
\end{array}
$$

Secara umum konsumen menyukai semua jenis olahan susu kambing yang diintroduksikan, hal ini terlihat dari skor penerimaan konsumen untuk semua hasil olahan susu kambing >3 atau masuk katagori suka (Tabel 1). Namun dari semua jenis olahan susu kambing yang diintroduksikan, konsumen paling menyukai jenis olahan susu kambing berupa es krim susu kambing rasa kweni, dengan skor penerimaan konsumen yang lebih tinggi dibandingkan dengan jenis olahan susu kambing lainnya baik dari warna, aroma, rasa, dan penerimaan umum. Hal ini mungkin disebabkan oleh buah kweni memiliki aroma khas yang disukai konsumen dan dapat menutupi aroma susu kambingnya.

Komponen-komponen susu yang terpenting adalah protein dan lemak.
Kandungan protein susu berkisar antara 3-5\% sedangkan kandungan lemak berkisar antara 3-8\%. Kandungan energi adalah $65 \mathrm{kkal}$, dan $\mathrm{pH}$ susu adalah 6,7 (Saleh, 2004). Hasil analisis kandungan mutu kambing segar yang digunakan pada penelitian ini yang disajikan dalam Tabel 2.

Produksi susu kambing PE di Indonesia masih sangat bervariasi berkisar antara 0,5-1.5 liter/ekor/hari (Tahahar et al., 1996). Secara kimiawi susu sapi normal mempunyai susunan sebagai berikut: air $(87,20 \%)$, lemak $(3,70 \%)$, protein $(3 \%)$, laktosa $(4,90 \%)$, dan mineral $(0,07 \%)$ (Sumudhita, 1989 dalam Hamidah, 2012). Kandungan protein susu kambing relatif lebih tinggi, yaitu $4,36 \%$ dibanding susu sapi $3 \%$ (Sunarlim, 1992). 


Hasil analisis laboratorium

(Tabel 2), menunjukkan bahwa susu kambing memiliki mutu gizi yang cukup baik dengan kandungan abusebesar $0,97 \%$ dan kandungan protein sebesar $4,36 \%$. Nilai ini lebih tinggi dibandingkan dengan kandungan gizi susu sapi yang memiliki kandungan abu sebesar $0,72 \%$ dan kandungan protein sebesar 3,4\%,selain itu susu kambing ini termasuk dalam katagori rendah lemak, hal ini terlihat dari kadar lemak susu kambing (Tabel 2) hanya sebesar 2,50\%, sementara kadar lemak susu sapi sebesar 3,9\% (Dewi, 2009 dalam Susilawati, 2011). Hai ini menunjukkan bahwa susu kambing mempunyai peluang yang baik untuk dikembangkan dalam bentuk hasilhasil olahan susu karena memiliki kandungan gizi yang sangat baik untuk kesehatan karena memiliki kandungan protein yang tinggi dan kandungan lemak yang rendah, sehingga dapat digunakan sebagai menu diet.

Tabel 2. Kandungan mutu susu kambing segar yang diujicobakan

\begin{tabular}{clc}
\hline No. & Parameter Pengamatan & Kandungan $(\%)$ \\
\hline 1. & Kadar air & 84,47 \\
2. & Kadar abu & 0,97 \\
3. & Kadar protein & 4,36 \\
4. & Kadar lemak & 2,50 \\
5. & Kadar serat kasar & 0,85 \\
6. & Kadar karbohidrat & 6,86 \\
\hline
\end{tabular}

Ljutovac et al., (2008) menyatakan, umumnya kadar lemak susu dipengaruhi oleh masa laktasi, musim, bangsa dan pakan. Kambing perah dalam penelitian ini mendapatkan pakan berupa ampas tahu 1,5 kg/ekor/hari, larutan gula merah 40 g/ekor/hari, dan fermentasi daun singkong $3 \mathrm{~kg} / \mathrm{ekor} / \mathrm{hari}$. Pemberian pakan hijauan berhubungan dengan kadar lemak susu yang dihasilkan. Kadar lemak yang rendah di dalam susu kambing pada penelitian ini diduga disebabkan oleh pemberian pakan hijauan yang kurang optimal untuk pembentukan lemak susu. Sukarini (2006), melaporkan bahwa dengan pemberian pakan hijauan yang optimal, kadar lemak susu kambing PE yang dihasilkan sebesar 4,86\%, sementara pada penelitian ini kadar lemak susu kambing yang dihasilkan hanya 2,50\%. Pakan hijauan merupakan sumber serat dankekurangan pakan serat akan menghasilkan susu dengan kadar lemak rendah. Hal ini disebabkan hijauan di dalam rumen merupakan sumber asam asetat yang merupakan bahan baku pembentuk berbagai asam lemak dari lemak susu yaitu butirat, kaproat, kaprilat, kaprat, laurat, miristat, palmitat, oleat, stearat, dan linolaet. Semakin banyak produksi asetat, semakin banyak sintesis asam lemak yang kemudian menyebabkan peningkatan kadar lemak susu. Menurut Standar Nasional Indonesia (2011), kadar lemak susu segar pada pemerahan pagi hari minimum 2,8\%, sedangkan menurut Thai Agriculture Standar (2008) kadar lemak susu kambing untuk kelas premium minimum $4,0 \%$.

Untuk mengetahui prospek pemasaran olahan susu kambing, telah dilakukan penghitungan titik impas olahan susu kambing yang diujicobakan. Dari data yang tertera dalam Tabel 3, 4, 5 , dan 6 diperoleh harga titik impas 
pembuatan produk olahan susu kambing berturut-turut: susu aroma rempah $\mathrm{Rp}$. 45.500,-/liter, es krim susu kambing rasa strawberry Rp.61.267,-/lt, susu kambing rasa kweni Rp. 55.933,-/lt, dan permen karamel susu kambing Rp. 1.479,-/buah. Analisa ekonomi B/C ratio produk belum dapat dihitung karena produk ini masih merupakan merupakan produk baru di lokasi penelitian dan petani belum mulai menjual produk olahan susu kambing yang diintroduksikan.

Pengembangan usaha kambing perah mempunyai peluang pasar yang cukup tinggi di KabupatenLampung Timur. Kebutuhan investasi usaha kambing perah jauh lebih kecil dibandingkan dengan sapi perah, lebih mudah dalam manajemen, sederhana, tidak membutuhkan tempat yang luas, dan perkembangbiakannya relatif lebih cepat dibandingkan dengan ternak besar. Selain itu, harga dan permintaan susu kambing memiliki prospek yang baik, karena susu kambing memiliki harga jual yang lebih tinggi dibandingkan susu sapi. Di lokasi penelitian susu kambing dapat dijual dengan harga $\mathrm{Rp} \mathrm{35.000,-/liter,}$ sedangkan susu sapi hanya berkisar $\mathrm{Rp}$ $10.000,-/$ liter. Harga susu yang tinggi dengan investasi yang jauh lebih kecil dibandingkan dengan usaha ternak sapi perah, membuat usaha ini mempunyai peluang yang baik untuk dikembangkan di masa yang akan datang.

Tabel 3. Harga titik impas susu kambing aroma rempah

\begin{tabular}{lccc}
\hline & Harga \\
No & Jumlah & $\begin{array}{c}\text { Satuan } \\
(\text { Rp) }\end{array}$ & Jumlah (Rp) \\
& & \\
\hline
\end{tabular}

\section{A. Bahan Kegiatan}

215.000

1. Susu kambing

2. Kayu manis

50

3. Jahe

$\begin{array}{rr}5 & \text { It } \\ 50 & \mathrm{~g}\end{array}$

180.000

3. Jahe

50

50

g

2.000

4. Gula merah

$50 \quad \mathrm{~g}$

2.000

5. Gas

$0,75 \quad \mathrm{~kg}$

1.000

6. Kemasan botol

5 buah

5.000

25.000

\section{Upah Tenaga Kerja}

12.500

Pembuatan susu kambing

1. aroma rempah

$0,25 \quad \mathrm{OH}$

50.000

12.500

B. Total Biaya Produksi

\section{Rendemen Susu}

Kambing Aroma

C. Rempah

Harga titik impas

pembuatan susu kambing

aroma rempah per liter

$5 \quad$ lt

$1 \quad$ lt 45.500 ,- 
Tabel 4. Harga titik impas es krim susu kambing rasa strawberry

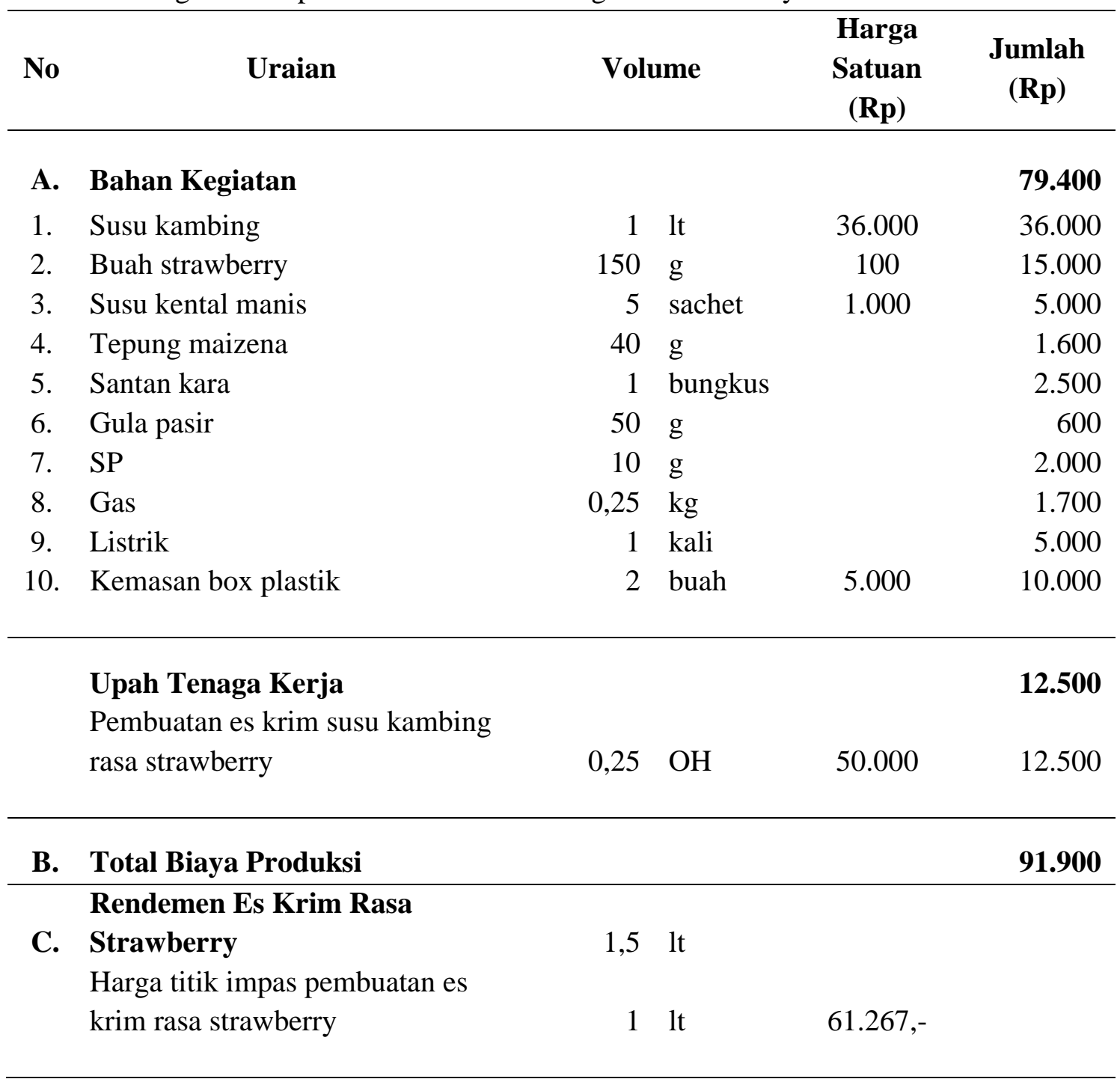

Tabel 5. Harga titik impas es krim susu kambing rasa kweni

\begin{tabular}{lccc}
\hline No & Uraian & Harga \\
& Volume & Satuan \\
& $($ Rp) & Jumlah (Rp) \\
\hline
\end{tabular}

A. Bahan Kegiatan

1. Susu kambing

2. Buah kweni

3. Susu kental manis

4. Tepung maizena

5. Santan kara

6. Gula pasir

7. SP

8. Gas

9. Listrik

10. Kemasan box plastik

\begin{tabular}{rlrr} 
& & $\mathbf{7 1 . 4 0 0}$ \\
1 & lt & 36.000 & 36.000 \\
2 & bh & 3.500 & 7.000 \\
5 & sachet & 1.000 & 5.000 \\
40 & g & & 1.600 \\
1 & bungkus & & 2.500 \\
50 & g & & 600 \\
10 & g & & 2.000 \\
0,25 & kg & & 1.700 \\
1 & kali & & 5.000 \\
2 & buah & 5.000 & 10.000 \\
\hline
\end{tabular}


Upah Tenaga Kerja

12.500

Pembuatan es krim susu

kambing rasa kweni

$0,25 \mathrm{OH}$

50.000

12.500

B. Total Biaya Produksi

83.900

Rendemen Es Krim Rasa

C. Kweni

$1,5 \quad$ lt

Harga titik impas pembuatan es

$1 \mathrm{lt}$

krim susu kambing rasa kweni

per liter

$55.933,-$

Tabel 6. Harga titik impas permen karamel susu kambing

\begin{tabular}{llrrrr}
\hline No & \multicolumn{1}{c}{ Uraian } & Volume & $\begin{array}{c}\text { Harga Satuan } \\
(\mathbf{R p})\end{array}$ & $\begin{array}{c}\text { Jumlah } \\
(\mathbf{R p})\end{array}$ \\
\hline A. & Bahan Kegiatan & & & & $\mathbf{3 1 . 8 7 5}$ \\
1. & Susu kambing & 0,5 & $\mathrm{lt}$ & 36.000 & 18.000 \\
2. & Gula pasir & 0,25 & $\mathrm{~kg}$ & 12.500 & 3.125 \\
3. & Blue Band & 125 & $\mathrm{~g}$ & & 6.250 \\
4. & Vanili & 15 & $\mathrm{ml}$ & & 500 \\
5. & Kertas minyak & 1 & buah & 1.000 & 1.000 \\
6. & Bahan bakar Gas & 1 & kali & & 3.000
\end{tabular}

Upah Tenaga Kerja

12.500

Pembuatan permen karamel

1. susu kambing

$0,25 \mathrm{OH}$

50.000

12.500

B. Total Biaya Produksi

44.375

Rendemen Permen Karamel

C. Susu Kambing

Harga titik impas pembuatan

1 buah

permen karemel susu kambing

per buah

\section{KESIMPULAN}

Hasil analisis laboratorium menunjukkan bahw nilai gizi susu kambing baik untuk kesehatan, karena memiliki kadar protein yang tinggi $(4,36 \%)$ dan kadar lemak $(2,5 \%)$ yang rendah. Kesukaan konsumen terhadap 
hasil olahan susu kambing yang diintroduksikan pada taraf disukai oleh konsumen, dengan nilai skor rata-rata $>3$. Hasil analisis titik impas menunjukkan bahwa pengolahan susu kambing memiliki prospek untuk dikembangkan, karena harga titik impasnya masih terjangkau konsumen yaitu: Rp.45.500,-/liter susu kambing aroma rempah; Rp.61.267/liter es krim susu kambing rasa starwberry, Rp.55.933,-/liter es krim susu kambing rasa kweni, dan Rp. 1.479/buah permen karamel susu kambing.

\section{DAFTAR PUSTAKA}

Arifin, A, A. Y. Oktaviana, R. R. S. Wihansah, M. Yusuf, Rifkhan, J. K. Negara, A. K. Sio. 2016. Kualitas Fisik, Kimia dan Mikrobiologi Susu Kambing pada Waktu Pemerahan yang Berbeda di Peternakan Cangkurawok, Balumbang Jaya, Bogor. Jurnal Ilmu Produksi dan Teknologi Hasil Peternakan. Vol. 04 (2): 291-295.

Badan Standarisasi Nasional. 2011. Susu

Segar (No. SNI 01-3141-2011). Jakarta (ID): Badan Standarisasi Nasional.

Dewi, A. 2009. Teknologi Pengolahan Susu (Karamel Susu). http:// www.blogspot.com//dewi/teknolog i/pengolahan/susu. Diakses pada tanggal 3 Agustus 2017.

Hamidah, E., I Made Sukada, Ida Bagus Ngurah Swacita. 2012. Kualitas Susu Kambing Peranakan Etawah Post-Thawing pada Penyimpanan Suhu Kamar. Indonesia Medicus Veterinus 1(3) : $361-369$.

Ljutovac, K.R., G. Lagtiffoul, P. Paccard,

I. Guillet And Y. Chilliard. 2008. Composition of goat and sheep milk product: An update. J. Small Rum. Res. 79: 57-72.

Effendi, M.H., Sorini Hartin, dan A.M. Lusiastuti. 2009. Peningkatan Kualitas Yoghurt dari Susu Kambing dengan Penambahan Bubuk Susu Skim dan Pengaturan Suhu Pemeraman, J. Penelit. Med. Eksakta, Vol. 8 (3): 185-19.

Saleh, E. 2004. Dasar Pengolahan Susu Dan Hasil Ikutan Ternak. Program Studi Produksi Ternak, Fakultas Pertanian Universitas Sumatera Utara. 24 hal.

Soekartawi. 1995. Analisis Usahatani. Penerbit Universitas Indonesia Jakarta. 43 hal.

Sudono, A., I.K. Abdulgani. \& H. Nadjib. 1989. Diktat Ilmu Produksi Ternak Perah. Jurusan Ilmu Produksi Ternak, Fakultas Peternakan. Bogor (ID): Institut Pertanian Bogor.

Sukarini, I.A.M. 2006. Produksi dan komposisi air susu kambing Peranakan Etawah yang diberi tambahan konsentrat pada awal laktasi. Majalah Ilmiah Petern. 9: 14-25.

Sumudhita, M.W. 1989. Air Susu dan Penanganannya. Program Studi Ilmu Produksi Ternak Perah. Fakultas Peternakan Universitas Udayana, Denpasar. Hal 1-45.

Sunarlim. 1992. Usaha Berternak Kambing Etawah. http://www.smallcrab.com/ Forex/172-usaha-beternak-etawah. Tanggal Akses 7 Agustus 2017

Tahahar A, Juarin E, Prianti A, Prianto D, Wibowo B. 1996. Usaha Kambing Erh Rakyat Sebagai Salah Satu Pendapatan Rumah Tangga Di Jawa Timur. Prosiding Ilmiah Hasil Penelitian Peternakan. BPPT Ciawi Pp 195-203 
Thai Agricultural Standard. 2008. Raw Goat Milk. National Bureau of Agricultural Commodity and Food Standards, Ministry of Agriculture and Cooperatives. ICS 67.100.01. Published in the Royal Gaze tte Vol. 125 Section 139 D. Thailand. 